University of California

Cooperative Extension 2020
UC ANR Publication 6711 | August 2020

https://doi.org/10.3733/ucanr.6711

\title{
UCCE Ranch Water Quality Planning Ranch Water Quality Plan Template
}
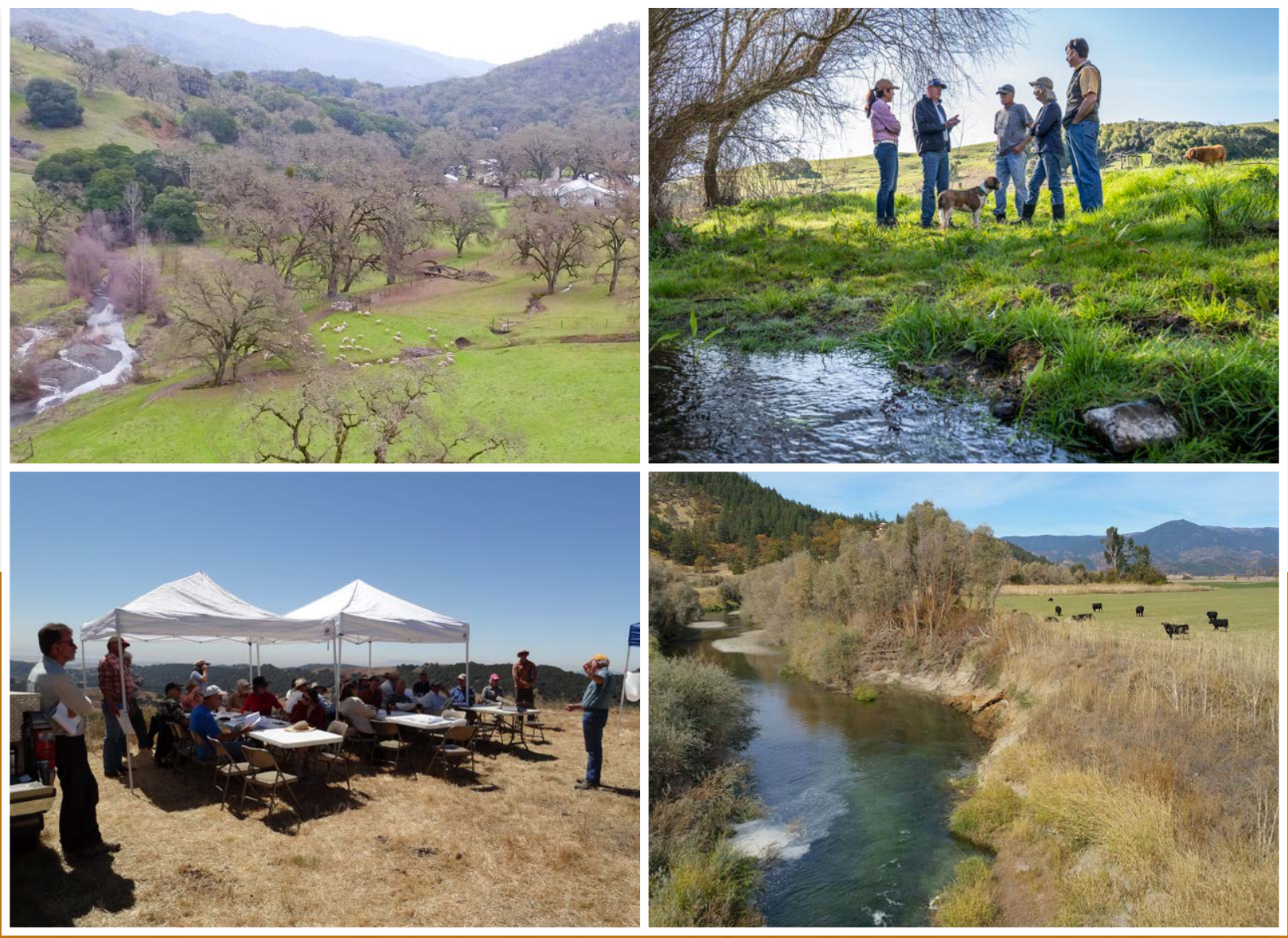

Morgan Doran, UC Cooperative Extension (UCCE); Michael Lennox, Olivet Ranch; and David Lewis, UCCE 


\section{Ranch/Farm Location}

Ranch/Farm Name:

Mailing Address, or P.O. Box:

County:

City, State, Zip Code:

Phone: Size (acres):

List all Assessor Parcel Numbers (APNs) or legal description (Township, Range, Sections) for each parcel, pasture, or silage field included in this plan:

1.

4.

7.

In which Water Board region(s) is the ranch/farm located?

R1 (North Coast)

R4 (Los Angeles)

R2 (San Francisco Bay)

R3 (Central Coast)
2.

5.

8.
R5 (Central Valley)

R6 (Lahontan)

R7 (Colorado River)

3.

6.

9.

\section{Owner}

Name(s):

Mailing Address or P.O. Box: same as ranch address

City, State and Zip Code:

Phone:

E-mail (optional):

\section{Tenant/Manager (if not owner)}

Name(s):

Mailing Address or P.O. Box: same as ranch address

City, State and Zip Code:

Phone:

E-mail (optional):

\section{Plans \& Certifications}

Check the box for the plans, certifications or other documents that exist for the ranch:

Conservation Easement

Dairy Quality Assurance Program

Erosion Control Plan

Fire Management Plan

Fish Friendly Farming

Grass-Fed Certification
Grazing Management Plan

UCCE Ranch Plan

Salmon Safe Certification

NRCS Conservation Plan

Dairy Nutrient Management

Dairy Waste Management Plan
Timber Harvest Plan

Organic Certification

Succession Plan 


\section{WORKSHEET 2 - RANCH GOALS}

Date(s) Updated:

Ranch goals are divided into production, quality of life and natural resource goals. These goals should reflect what you are trying to accomplish on your property. They are used to identify management strategies and practices for accomplishing your goals as well as to help you identify goals that might conflict with each other. Check any goal statements below which reflect your plans, reword them if needed and/or write-in your own. Consider prioritizing them in discussions with family and managers.

\section{Production}

pass on the farm/ranch to the next generation

reduce family/farm debt

expand farm/ranch enterprises

develop new enterprises

increase farm/ranch profitability reduce operating costs

purchase or lease more ranch/farm property

\section{Quality of Life}

reduce energy consumption in the farm/ranch operation

provide for our children's college education

provide financial or other support for community organizations

reduce household operating expenses

\section{Natural Resources \& Water Quality}

manage rangeland to protect soil from erosion

manage cropland, pastureland or forestland to protect soil from erosion

manage ranch roads to reduce movement of sediment into streams and other water bodies

reduce erosion of streambanks and gullies

manage to increase tree cover and/or ground cover in riparian areas or along streams

reduce concentration of livestock in or near streams, wetlands, or other water bodies

manage to reduce entry of sediment, nutrients and pathogens to streams or wetlands build an emergency fund

raise livestock or crops during retirement

build a retirement fund reduce wildfire hazard

maintain or enhance oak woodland, native grass, or other plant communities

maintain or enhance wildlife or fisheries habitat or other aquatic resources

reduce/manage invasive weeds

reduce/manage predator impacts on the ranching operation

meet water quality regulations 


\section{WORKSHEET 3 - PASTURE INVENTORY}

Date(s) Updated:

Describe each pasture, paddock and open rangeland on the ranch/farm with estimations of area, slope, and woody vegetation cover. Large or complex pastures may be subdivided into subsection units for management and/or mapping purposes. Look up the minimum objective for Residual Dry Matter (RDM) monitoring in Tables 1-3 from https://anrcatalog.ucanr.edu/pdf/8092.pdf and note Table \# used. Soil information is here: https:// casoilresource.lawr.ucdavis.edu/gmap/ and http://websoilsurvey.nrcs.usda.gov/app/.

\section{PASTURE/FIELD INVENTORY}

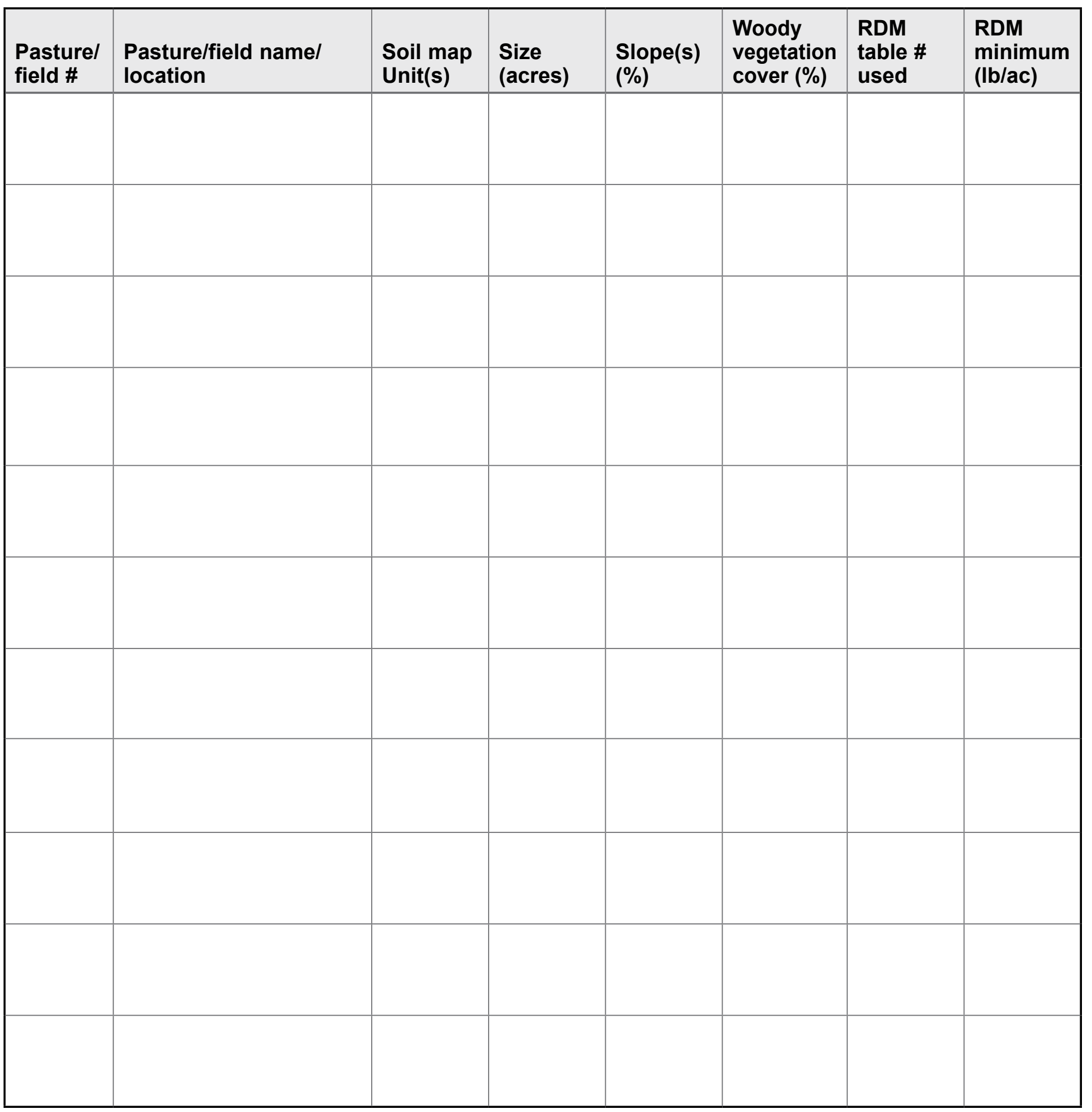




\section{WORKSHEET 4A- PASTURE ASSESSMENT: SEDIMENT}

Date(s) Updated:

The following questions are intended to help assess ranch/farm water quality and potential sources of pollution in the watershed. It is important to note that identified pollution sources may not be caused by current livestock grazing activities. This assessment is intended to be used on each pasture/field utilized for agricultural production purposes on the ranch/farm. Multiple fields or the entire ranch may be assessed at once. Describe the condition and pasture/field location. Note any recorded problem conditions as caused by: Current livestock management $(\mathrm{C})$; a Historic legacy site $(\mathrm{H})$; or Natural causes $(\mathrm{N})$. For more information, refer to the publications Understanding Livestock Grazing Impacts or Sediment Delivery Inventory and Monitoring.

\section{SEDIMENT}

\begin{tabular}{|c|c|c|c|}
\hline \multicolumn{4}{|l|}{ Rangeland \& pasture fields } \\
\hline Question & $\begin{array}{l}\text { Potential } \\
\text { source }\end{array}$ & Pasture location and description of condition & $\begin{array}{l}\text { Cause } \\
\text { C / H / N }\end{array}$ \\
\hline $\begin{array}{l}\text { Bare soil visible throughout the } \\
\text { rainy season? }\end{array}$ & $\begin{array}{l}\text { Yes No } \\
\text { Not Sure }\end{array}$ & & $\begin{array}{ll}\mathrm{C} & \mathrm{H} \\
\mathrm{N} & \end{array}$ \\
\hline Rill or sheet erosion present? & $\begin{array}{l}\text { Yes No } \\
\text { Not Sure }\end{array}$ & & $\begin{array}{l}\mathrm{C} \\
\mathrm{N}\end{array}$ \\
\hline $\begin{array}{l}\text { Gullies, slumps, or headcuts } \\
\text { present? }\end{array}$ & $\begin{array}{l}\text { Yes No } \\
\text { Not Sure }\end{array}$ & & $\begin{array}{l}\mathrm{C} \\
\mathrm{N}\end{array}$ \\
\hline \multicolumn{4}{|l|}{ Roads } \\
\hline Question & $\begin{array}{l}\text { Potential } \\
\text { source }\end{array}$ & Pasture location and description of condition & $\begin{array}{l}\text { Cause } \\
\text { C / H / N }\end{array}$ \\
\hline $\begin{array}{l}\text { Surface erosion present on } \\
\operatorname{road}(\mathrm{s}) \text { (rills, gullies)? }\end{array}$ & $\begin{array}{l}\text { Yes No } \\
\text { Not Sure }\end{array}$ & & $\begin{array}{l}\mathrm{C} \\
\mathrm{N}\end{array}$ \\
\hline $\begin{array}{l}\text { Culverts or ditches cause } \\
\text { gullies or erosion? }\end{array}$ & $\begin{array}{l}\text { Yes } \quad \text { No } \\
\text { Not Sure }\end{array}$ & & $\begin{array}{l}\mathrm{C} \quad \mathrm{H} \\
\mathrm{N}\end{array}$ \\
\hline $\begin{array}{l}\text { Sediment fills drainage ditches } \\
\text { after winter? }\end{array}$ & $\begin{array}{l}\text { Yes No } \\
\text { Not Sure }\end{array}$ & & $\begin{array}{ll}\mathrm{C} & \mathrm{H} \\
\mathrm{N} & \end{array}$ \\
\hline
\end{tabular}




\section{WORKSHEET 4B - PASTURE ASSESSMENT: PATHOGENS AND NUTRIENTS}

Date(s) Updated:

The following questions are intended to help assess ranch/farm water quality and potential sources of pollution in the watershed. It is important to note that identified pollution sources may not be caused by current livestock grazing activities. This assessment is intended to be used on each pasture/field utilized for agricultural production purposes on the ranch/farm. Multiple fields or the entire ranch may be assessed at once. Describe the condition and pasture/field location. Note any recorded problem conditions as caused by: Current livestock management $(\mathrm{C})$; a Historic legacy site $(\mathrm{H})$; or Natural causes $(\mathrm{N})$. For more information, refer to the publications Understanding Livestock Grazing Impacts or Sediment Delivery Inventory and Monitoring.

\section{PATHOGENS AND NUTRIENTS}

\begin{tabular}{|c|c|c|c|}
\hline \multicolumn{4}{|l|}{ Livestock distribution } \\
\hline Question & $\begin{array}{l}\text { Potential } \\
\text { source }\end{array}$ & Pasture location and description of condition & $\begin{array}{l}\text { Cause } \\
\text { C / H / N }\end{array}$ \\
\hline $\begin{array}{l}\text { Storm runoff from corrals } \\
\text { connects to stream? }\end{array}$ & $\begin{array}{l}\text { Yes No } \\
\text { Not Sure }\end{array}$ & & $\begin{array}{ll}\mathrm{C} & \mathrm{H} \\
\mathrm{N} & \end{array}$ \\
\hline $\begin{array}{l}\text { Corrals used throughout the } \\
\text { winter? }\end{array}$ & $\begin{array}{l}\text { Yes No } \\
\text { Not Sure }\end{array}$ & & $\begin{array}{l}\mathrm{C}-\mathrm{H} \\
\mathrm{N}\end{array}$ \\
\hline $\begin{array}{l}\text { Feeding, salting, or watering } \\
\text { areas near stream? }\end{array}$ & $\begin{array}{l}\text { Yes No } \\
\text { Not Sure }\end{array}$ & & $\begin{array}{ll}\mathrm{C} & \mathrm{H} \\
\mathrm{N} & \end{array}$ \\
\hline $\begin{array}{l}\text { Do livestock congregate in the } \\
\text { stream? }\end{array}$ & $\begin{array}{l}\text { Yes No } \\
\text { Not Sure }\end{array}$ & & $\begin{array}{ll}\mathrm{C} & \mathrm{H} \\
\mathrm{N} & \end{array}$ \\
\hline \multicolumn{4}{|c|}{ Compost \& manure management } \\
\hline Question & $\begin{array}{l}\text { Potential } \\
\text { source }\end{array}$ & Pasture location and description of condition & $\begin{array}{l}\text { Cause } \\
\mathrm{C} / \mathrm{H} / \mathrm{N}\end{array}$ \\
\hline $\begin{array}{l}\text { Compost stockpile runoff } \\
\text { connects to stream? }\end{array}$ & $\begin{array}{l}\text { Yes No } \\
\text { Not Sure }\end{array}$ & & $\begin{array}{ll}\mathrm{C} & \mathrm{H} \\
\mathrm{N} & \end{array}$ \\
\hline $\begin{array}{l}\text { Compost applied to pasture } \\
\text { less than } 2 \text { weeks before a } \\
\text { runoff generating rain storm? }\end{array}$ & $\begin{array}{l}\text { Yes No } \\
\text { Not Sure }\end{array}$ & & $\begin{array}{ll}\mathrm{C} & \mathrm{H} \\
\mathrm{N} & \end{array}$ \\
\hline $\begin{array}{l}\text { Compost applied to pastures } \\
\text { is stored (aged) less than one } \\
\text { month? }\end{array}$ & $\begin{array}{l}\text { Yes No } \\
\text { Not Sure }\end{array}$ & & $\begin{array}{l}\mathrm{C}-\mathrm{H} \\
\mathrm{N}\end{array}$ \\
\hline
\end{tabular}


Date(s) Updated:

This assessment is intended for perennial or intermittent streams that provide habitat for fish or frogs or support riparian vegetation. If you do not have streams with riparian vegetation, assess the larger intermittent stream channels that flow during the entire rainy season. Assess ranch/farm streams while standing near the creek. It is important to note that concerns identified may not be caused by current livestock grazing activities. Describe the condition and location. Note any recorded problem conditions as caused by: Current livestock management (C); a Historic legacy site $(\mathrm{H})$; or Natural causes $(\mathrm{N})$. For more information, refer to the publication Visual Assessment of Riparian Health.

\section{STREAM CHANNEL}

\begin{tabular}{|l|c|c|c|}
\hline Question & $\begin{array}{l}\text { Potential } \\
\text { source }\end{array}$ & $\begin{array}{c}\text { Pasture location and description } \\
\text { of condition }\end{array}$ & $\begin{array}{l}\text { Cause } \\
\text { C / H / N }\end{array}$ \\
\hline Bare soil along banks of stream? & $\begin{array}{l}\text { Yes No } \\
\text { Not Sure }\end{array}$ & C \\
\hline Unstable or eroding stream banks? & Yes No & Not Sure & C H \\
\hline $\begin{array}{l}\text { Does the stream have the potential to } \\
\text { support trees (look for remnant trees/ } \\
\text { shrubs along the channel)? }\end{array}$ & Yes No & Not Sure & C \\
\hline $\begin{array}{l}\text { Are stream crossings for livestock } \\
\text { unstable? }\end{array}$ & Yes No & H \\
\hline $\begin{array}{l}\text { Grazing in riparian areas takes place } \\
\text { all season? }\end{array}$ & Yes Not Sure & Not Sure & C \\
\hline
\end{tabular}

\section{STREAM TEMPERATURE}

\begin{tabular}{|c|c|c|c|}
\hline Question & $\begin{array}{l}\text { Potential } \\
\text { source }\end{array}$ & $\begin{array}{l}\text { Pasture location and description } \\
\text { of condition }\end{array}$ & $\begin{array}{l}\text { Cause } \\
\text { C / H / N }\end{array}$ \\
\hline Is stream exposed to full sun? & $\begin{array}{l}\text { Yes No } \\
\text { Not Sure }\end{array}$ & & $\begin{array}{ll}\mathrm{C} & \mathrm{H} \\
\mathrm{N} & \end{array}$ \\
\hline Are streams wide and shallow? & $\begin{array}{l}\text { Yes No } \\
\text { Not Sure }\end{array}$ & & $\begin{array}{ll}\mathrm{C} & \mathrm{H} \\
\mathrm{N} & \end{array}$ \\
\hline $\begin{array}{l}\text { Does stream flow appear inadequate, } \\
\text { given stream channel size? }\end{array}$ & $\begin{array}{l}\text { Yes No } \\
\text { Not Sure }\end{array}$ & & $\begin{array}{l}\mathrm{C} \\
\mathrm{N}\end{array}$ \\
\hline
\end{tabular}

\section{NUTRIENTS}

\begin{tabular}{|l|l|c|c|}
\hline Question & $\begin{array}{l}\text { Potential } \\
\text { source }\end{array}$ & $\begin{array}{c}\text { Pasture location and description } \\
\text { of condition }\end{array}$ & $\begin{array}{c}\text { Cause } \\
\text { C / H / N }\end{array}$ \\
\hline Algae growth excessive in stream? & Yes No & & $\mathrm{C}$ \\
Not Sure & & $\mathrm{N}$ \\
\hline $\begin{array}{l}\text { Does stream have an unusual color } \\
\text { or appearance? }\end{array}$ & $\begin{array}{l}\text { Yes No } \\
\text { Not Sure }\end{array}$ & & $\mathrm{C}$ \\
$\mathrm{H}$
\end{tabular}




\section{WORKSHEET 6 - COMPLETED WATER QUALITY PROJECTS}

Date(s) Updated:

List all past water quality concerns on the ranch/farm and describe the issue. A concern does not indicate that livestock grazing or current management caused it. Describe any previously implemented management practice(s) intended to fix the problem. This includes steps to plan or receive technical or financial assistance (phone calls, ranch visits, applications, etc.), actual implementation or management changes (fencing, seeding, headcut repairs, etc.), and the maintenance of projects or ranch infrastructure (cleaning culverts, scraping corrals, weed removal, etc.). Evaluate if more work is needed to improve water quality for each listed concern. Attach any old photographs of the concern including work completed if available. Use additional sheets if needed.

WATER QUALITY CONCERN

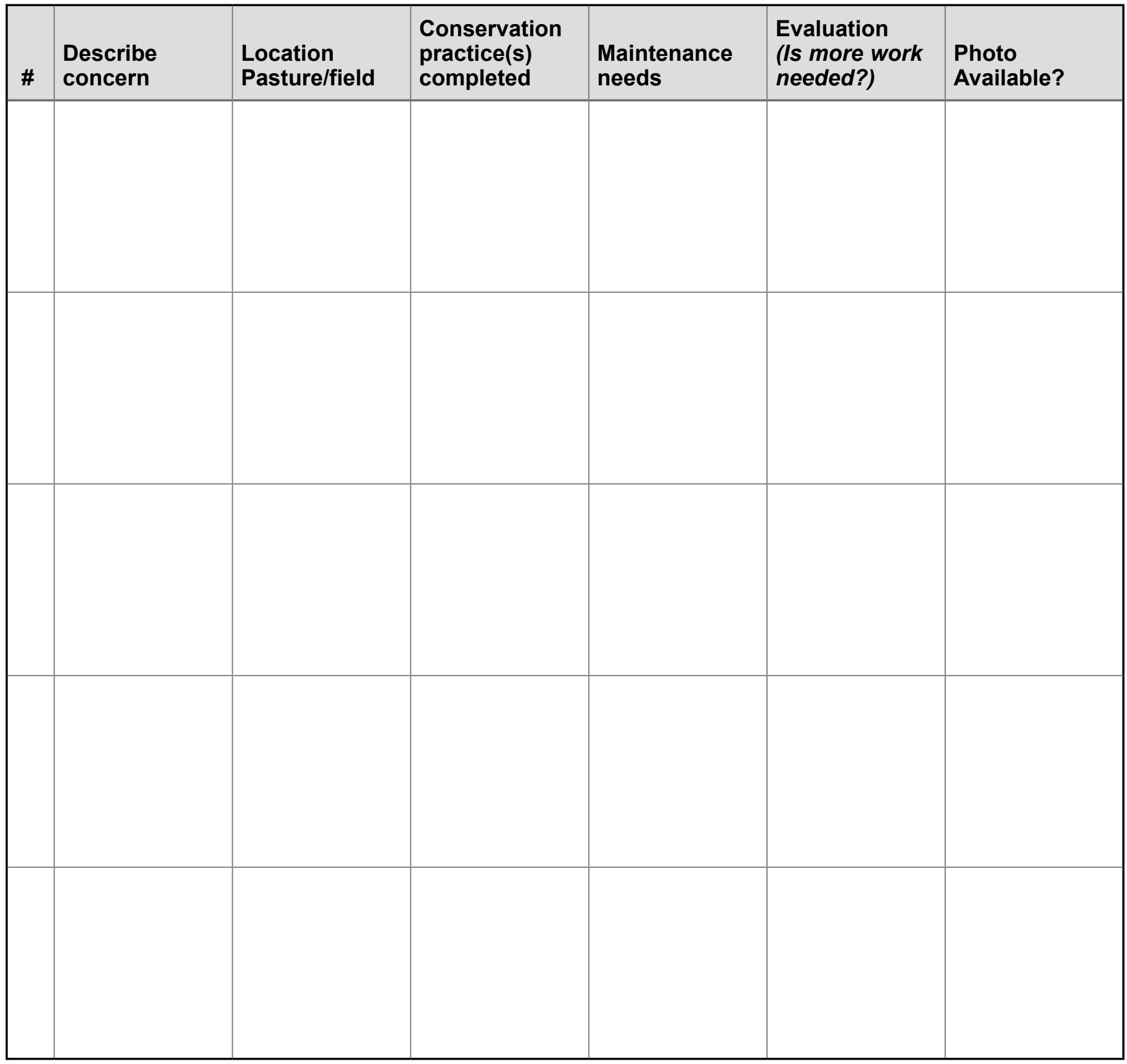




\section{WORKSHEET 7 - FUTURE WATER QUALITY PROJECTS}

Date(s) Updated:

List all future potential water quality concerns on the ranch/farm with the expected pollutants from each. A concern does not indicate that livestock grazing or current management caused it. This includes locations where your current maintenance prevents problems such as maintaining ranch roads following winter storms. Consider multiple options for fixing water quality concerns such as implementing new practices, and changing management or maintenance routines. Estimate the approximate cost of each option as well as the amount of time needed to conduct maintenance. Give each project a priority, relative to other potential projects, indicating preferred order implementing the project. Assignment of priority recognizes that the availability of financial and technical assistance determines when work is done. List the steps taken to plan for the project including participation in technical \& financial assistance programs (ranch visits, meetings, applications, expected contract dates, etc). Use additional sheets if needed.

\section{FUTURE WATER QUALITY CONCERN}

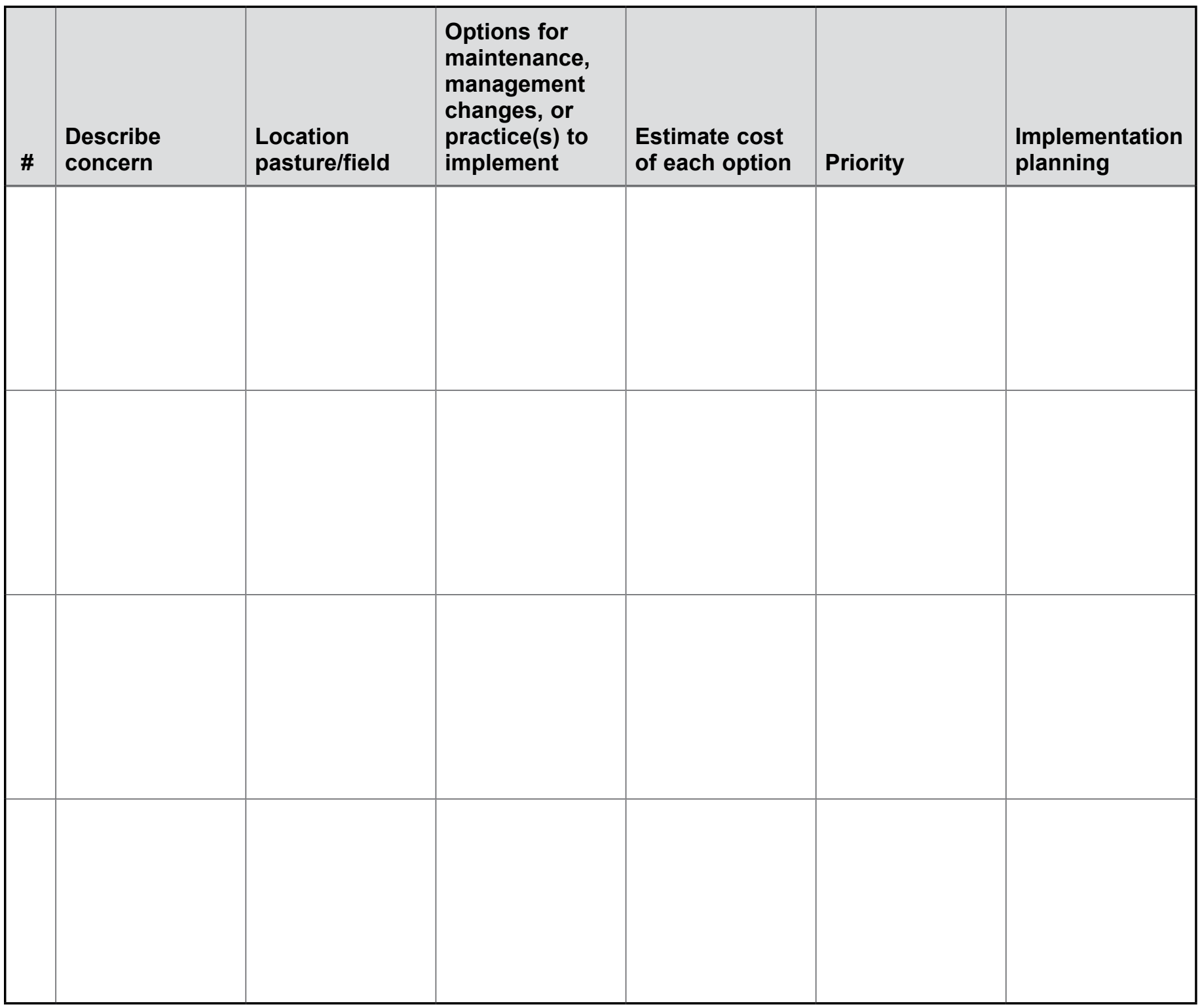




\section{WORKSHEET 8 - MAPPING RANCH FACILITIES}

\section{MAPPING}

Note the type, scale and features added on ranch maps. The map scale should be 1 inch : 12,000 feet, or finer resolution. Contact your local RCD or NRCS for assistance. Online mapping resources are available from the UC Davis California Soil Resources Lab and the USDA-NRCS Web Soil Survey. Additional mapping resources are available from Google, either as Google Earth (a website platform) or with Google Earth Pro (a downloadable software program with expanded mapping features.

\section{Which map types are being used for this ranch plan?}

Topographic (USGS Quadrangle)

Aerial photograph(s) - Dates:

Soil map units

What is the scale of your map(s)?

$1: 12,000$

Locate the following important ranch/farm features on your map and attach the map to this plan:

Property lines for each APN Leased pastures or rangeland

Barns, holding areas or corrals

Ranch roads, ponds, bridges or culverts

Pastures, fence lines or gates

Future water quality projects

Completed water quality projects

Monitoring points for photographs, visual inspections or Residual Dry Matter (RDM)

Water troughs, tanks, spring developments or pipelines

Supplements, minerals or salt blocks

\section{WATERSHED ASSESSMENT}

What types of stream(s) are on the ranch/farm?

Name(s) of stream(s) on your ranch/farm (if named):

Name of creek, river, waterbody or wetland downstream (lake, bay, etc.):

Is a municipal or domestic water supply source downstream?

$\checkmark$ Yes

No

Not Sure 


\section{WORKSHEET 9 - PASTURE USE RECORDS}

Date(s) Updated:

Record how and when pasture/rangeland is utilized by livestock during the year. Note the livestock number, animal type, dates in and dates out of each pasture unit. This information can be used to calculate stocking rates and carrying capacity. Note pasture/animal needs (mineral, trough, seed, etc.). For more information, refer to http://rangelandarchive.ucdavis.edu/files/252897.pdf. For a detailed Prescribed Grazing tool, go to http://efotg. sc.egov.usda.gov/references/public/CA/TN_CA_Range_54.pdf.

\section{PASTURE USE}

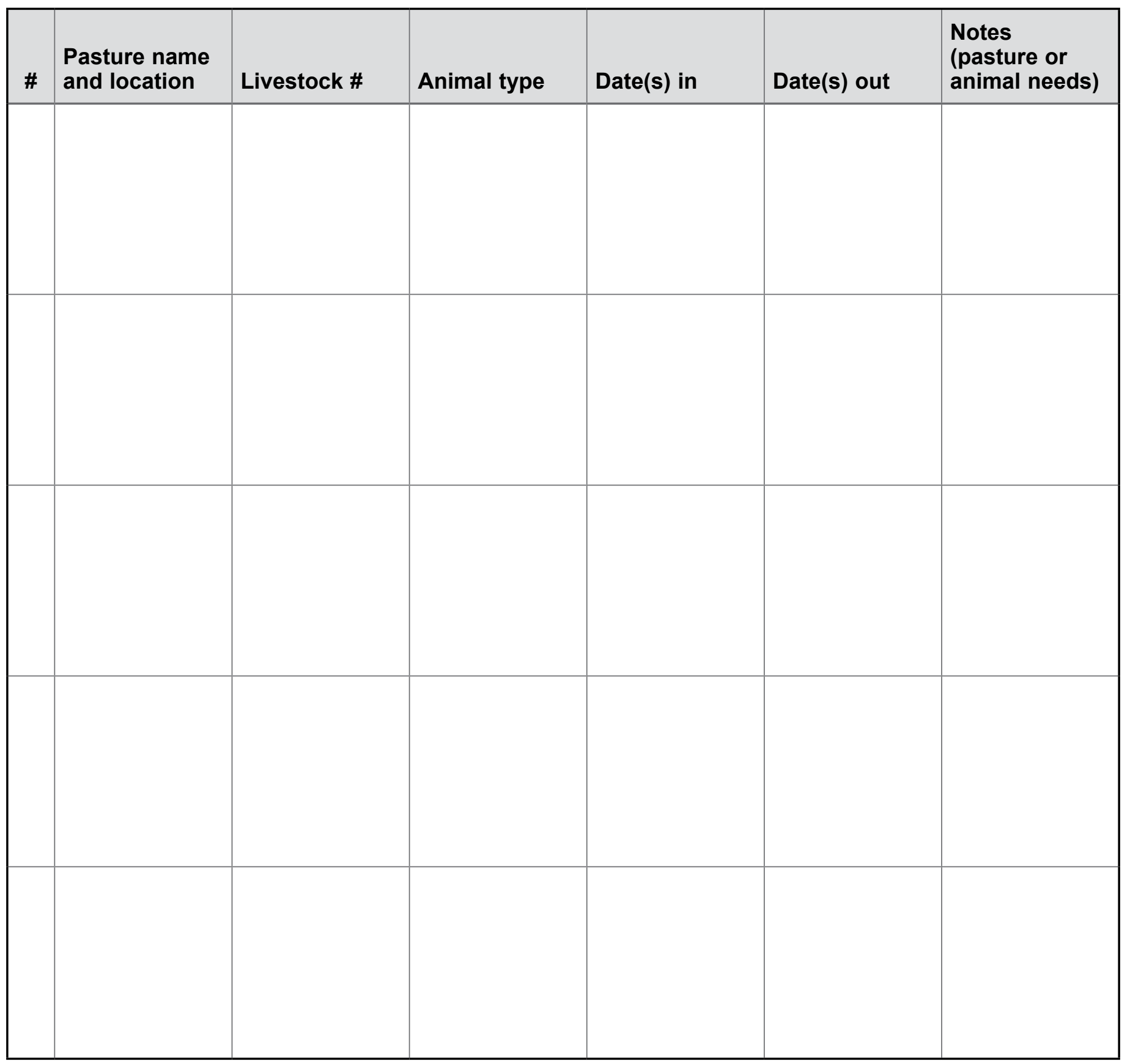




\section{WORKSHEET 10 - VISUAL, RESIDUAL DRY MATTER (RDM) AND PHOTO MONITORING}

\section{Visual Inspections}

Annual visual monitoring can be done to capture the general readiness of the ranch for the oncoming wet season, and general ranch water quality conditions during the wet season. Visual monitoring can consist of:

- Two dry season inspections including one in September of the entire ranch prior to the rainy season.

- Wet season inspections of the ranch following storms or every month (Dec.-April).

- One stream survey above and below or upstream and downstream of the ranch.

Use these inspections with Pasture and Stream Assessments (RWQP Worksheets $4 \& 5$ ) to decide if further management practices are needed to improve water quality on the ranch. For rangeland health indicators, refer to the Rangeland Health Assessment guide from the Natural Resources Conservation Service.

Start the yearly task of compliance monitoring on the ranch in September, at the onset of the rainy season. Follow this up with two wet season inspections and one inspection in the late-spring. The late-spring inspection can be used to plan conservation practice implementation before the winter rains arrive. To monitor more efficiently conduct the stream survey above and below the ranch during one of the wet season or dry season inspections.

In the table below, note the results of monitoring activities for field observations of potential water quality concerns found during visual inspections, estimates of Residual Dry Matter (RDM), and photographs taken

\section{Residual Dry Matter (RDM) and Photo- Monitoring}

Estimate RDM in the fall by visual and clip/dry/weigh methods. A useful guide for estimating RDM is available from Wildland Solutions. Interpret data as less $(<)$, equal $(=)$, or above (>) the minimum RDM objective for each pasture using the Pasture Inventory (RWQP Worksheet 3). Refer to Guidelines for Residual Dry Matter (RDM) Management.

Photographs are taken from the same location over time to document 1) RDM monitoring, 2) implemented conservation practices such as upgrading culverts, and 3 ) improvements at a site over time such as increased vegetation cover. List and describe the locations of photopoints and attach photos if possible. Refer to PhotoMonitoring for Better Land Use Planning \& Assessment.

\begin{tabular}{|c|c|c|c|}
\hline \multirow[t]{2}{*}{ Date } & \multirow[t]{2}{*}{$\begin{array}{l}\text { Location } \\
\text { (pasture/site) }\end{array}$} & $\begin{array}{l}\text { RDM estimate } \\
\text { (check method, photo, minimum) }\end{array}$ & \multirow[t]{2}{*}{$\begin{array}{l}\text { Visual inspection observations, } \\
\text { RDM explanations and notes }\end{array}$} \\
\hline & & 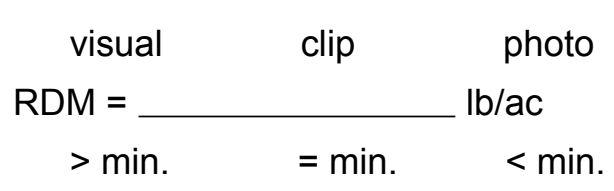 & \\
\hline & & $\begin{array}{lll}\text { visual } & \text { clip } & \text { photo } \\
\text { RDM }= & & \mathrm{lb} / \mathrm{ac} \\
>\min . & =\min . & <\min .\end{array}$ & \\
\hline & & $\begin{array}{lll}\text { visual } & \text { clip } & \text { photo } \\
\text { RDM }= & & \text { Ib/ac } \\
>\text { min. } & =\text { min. } & <\min .\end{array}$ & \\
\hline & & 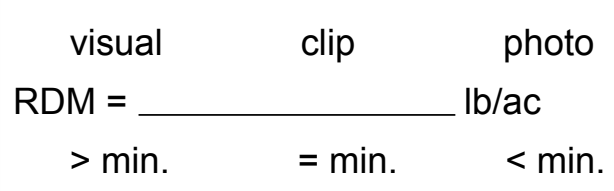 & \\
\hline & & $\begin{array}{ccc}\text { visual } & \text { clip } & \text { photo } \\
\text { RDM }= & \text { lb/ac } \\
>\text { min. } & =\text { min. } & <\text { min. }\end{array}$ & \\
\hline
\end{tabular}

